\title{
Utilization of green algae Caulerpa racemosa as feed ingredient for tiger shrimp Penaeus monodon
}

\section{Pemanfaatan rumput laut Caulerpa racemosa sebagai bahan baku pakan udang windu Penaeus monodon}

\author{
Widya Puspitasari' ${ }^{1}$, Dedi Jusadi ${ }^{1}$, Mia Setawati', Julie Ekasari' ${ }^{1}$, Abidin Nur², Iwan \\ Sumantri ${ }^{2}$ \\ 'Department of Aquaculture, Faculty of Fisheries and Marine Sciences, IPB University (Bogor Agricultural \\ University) \\ ${ }^{2}$ Main Center for Brackishwater Aquaculture Development Jepara Central Java, Indonesia. \\ *Corresponding author: D. Jusadi, siflounder@gmail.com
}

(Received August 4, 2017; Accepted May 15, 2019)

\begin{abstract}
The study aimed to evaluate the utilization of seaweed Caulerpa racemosa as feed ingredient for tiger shrimp Penaeus monodon. This research consisted of two different stages, i.e. digestibility and growth test. Tiger shrimp with average body weight of $5.70 \pm 0.42 \mathrm{~g}$ was reared during digestibility test. The measured parameters were total protein, calsium, magnesium, and energy digestibility. The growth test was managed by using a completely randomized design consisted of four different treatments (in triplicates) of dietary $C$. racemosa meal addition levels, i.e. 0 (control), 10, 20, and 30\%. Tiger shrimp with an average body weight of $0.36 \pm 0.02 \mathrm{~g}$ were cultured for 42 days in plastic containers $(70 \times 45 \times 40 \mathrm{~cm})$ with a stocking density of 15 shrimp/container. Apparent dry matter, protein, calcium, magnesium, and energy digestibilities of $C$. racemosa were 51.82, 88.67, 68.44, 16.39, $60.30 \%$, respectively. The results presented that the growth performance of tiger shrimp fed with diet containing $10 \%$ of $C$. racemosa was not significantly different with the control $(\mathrm{P}>0.05)$. However, the growth performance of the shrimp fed with diet containing more than $20 \%$ of $C$. racemosa decreased. The enzyme activitity of superoxide dismutase (SOD) increased with the higher level of dietary addition of $C$. racemosa. It can be concluded that $C$. racemosa was possibly applied up to $10 \%$ in the feed formulation for tiger shrimp.
\end{abstract}

Keywords: Caulerpa racemosa, Penaeus monodon, digestibility, growth performance, shrimp

\begin{abstract}
ABSTRAK
Penelitian ini bertujuan mengevaluasi pemanfaatan rumput laut Caulerpa racemosa sebagai bahan baku pakan udang windu Penaeus monodon. Penelitian ini dilakukan dengan dua tahap, yaitu uji kecernaan C. racemosa dan uji pertumbuhan udang. Udang windu yang digunakan pada uji kecernaan berbobot 5,70 $\pm 0,42 \mathrm{~g}$. Parameter uji yang diukur meliputi kecernaan total, protein, kalsium, magnesium, dan energi. Uji pertumbuhan dilakukan menggunakan rancangan acak lengkap dengan empat perlakuan dan tiga ulangan, yaitu penggunaan tepung $C$. racemosa sebesar 0 (kontrol), 10,20, dan 30\%. Udang windu dengan bobot 0,36 $\pm 0,02 \mathrm{~g}$ dipelihara dalam wadah kontainer plastik ukuran $70 \times 45 \times 40 \mathrm{~cm}$ (volume air sebanyak $90 \mathrm{~L}$ ) dengan kepadatan 15 ekor tiap wadah selama 42 hari. Hasil penelitian menunjukkan kecernaan total C. racemosa pada udang windu $51,82 \%$, kecernaan protein 88,67\%, kecernaan kalsium 68,44\%, kecernaan magnesium 16,39\%, dan kecernaan energi 60,30\%. Penelitian tahap kedua pada kinerja pertumbuhan udang yang mengonsumsi pakan mengandung $10 \%$ C. racemosa, tidak memberikan nilai yang berbeda nyata dengan udang yang mengonsumsi pakan kontrol. Namun, kinerja pertumbuhan udang menurun setelah mengonsumsi pakan yang mengandung C. racemosa di atas 20\%, sedangkan aktivitas enzim superoxide dismutase (SOD) meningkat. Dari penelitian ini dapat disimpulkan bahwa penambahan C. racemosa ke dalam formula pakan sampai $10 \%$ dapat digunakan sebagai bahan baku pakan udang windu.
\end{abstract}




\section{INTRODUCTION}

For many years, the main source of vegetable protein for shrimp feed was obtained from terrestrial plant, such as soybean meal (CruzSuarez et al., 2009; Suárez et al., 2009; Derby et al., 2016; Sharawy et al., 2016; Xie et al., 2016), lupin meal (Draganovic et al., 2014), garden pea Pisum sativum, concentrated rice protein (Oujifard et al., 2012; Chen et al., 2017), and canola meal Brassica sp. (Kou et al., 2015; Suárez et al., 2009; Singh et al., 2014). The ingredient selection is managed according to the nutrition and the digestibility (Cruz-Suarez et al., 2009; Samuelsen et al., 2014). However, those main sources contend with the livestock needs, thus the sustainability is uncertainty (Dolomatov et al., 2014; Schader et al., 2015). Moreover, the existance of antinutrition, such as phytate acid, tannin, and anti trypsin, causes downturn in nutrition absorption (Zhou et al., 2015; Difo et al., 2015). Therefore, further study about the other source of vegetable protein with low anti nutrition level is necessary.

Caulerpa racemosa is one of the marine algae species which is potentially developed as the shrimp feed ingredient. Paul et al. (2013) stated that the application of Caulerpa racemosa was able to boost high growth rate (5-7\%/day) (Paul et al., 2013). Caulerpa racemosa has a high nutrient content, i.e. protein $12.88-23.42 \%$, carbohydrate $27.2-48.10 \%$, and fat $0.3-2.64 \%$ (Kumar et al., 2011; Murugaiyan \& Narasimman, 2013). The calcium and magnesium content is higher as well compared to the terrestrial plant (MacArtain et al., 2007; Kalaivanan et al., 2012; Paul et al., 2013). Caulerpa sp. contains calcium and magnesium around $5.97 \%$ and $0.4-4.1 \%$, respectively (Santoso et al., 2006; Kumar et al., 2011; Gaillande et al., 2016). According to Matanjun et al. (2009), Caulerpa lentillifera contains approximately $329.69 \mathrm{mg} / 100 \mathrm{~g}$ of calcium and $271.33 \mathrm{mg} / 100 \mathrm{~g}$ of magnesium. $C$. racemosa has $8.958-11.31 \mathrm{mg} / \mathrm{g}$ of carotenoids which also acts as antioxidant, regulates cell growth, modulates gene expression, and induces immunity. Vitamin C (10.10-34.70 mg/100 g of wet weight) and vitamin $\mathrm{E}(1.1-9.4 \mathrm{mg} / 100$ $\mathrm{g}$ of wet weight) in C. racemosa are considered as vigorous antioxidant to increase the immunity against disease and oxidative stress (Gaillande $e t$ al., 2016). In spite of delivering high nutrition, C. racemosa also produces secondary metabolite named caulerpin (Felline et al., 2012; Nagappan \& Vairappan, 2014). The effect of caulerpin towards aquatic species, especially shrimp, has not been reported. Hence, the study was held to evaluate $C$. racemosa as feed ingredient for tiger shrimp Penaeus monodon.

\section{MATERIALS AND METHODS}

\section{Experiment I: Digestibility test}

Experimental feed preparation

C. racemosa was obtained from the coastal area of Kartini Beach, Jepara. C. racemosa was dried using an oven in temperature of $60-80^{\circ} \mathrm{C}$ for 48 hours. The dry weight was used in proximate analysis. It contained $30.03 \%$ of protein, $1.76 \%$ of crude fat, $3.29 \%$ of crude fiber, $22.22 \%$ of ash, and $42.70 \%$ of nitrogen-free extract (NFE). The commercial feed was used as base feed which is destructed then repelleting. The experimental feed is the combination of base feed and C. racemosa meal in ration 7:3 (NRC, 2011). The detail is shown below in Table 1 .

Table 1. The composition of experimental feed for digestibility test of C. racemosa.

\begin{tabular}{ccc}
\hline Ingredients (\%) & Base feed & $\begin{array}{c}\text { Experimental } \\
\text { feed }\end{array}$ \\
\hline Commercial feed & 97.50 & 67.50 \\
C. racemosa meal & 0.00 & 30.00 \\
$\mathrm{Cr}_{2} \mathrm{O}_{3}$ & 0.50 & 0.50 \\
Carboxymethyl & 2.00 & 2.00 \\
cellulose (CMC) & & 100.00 \\
\hline Total & 100.00 & \\
\hline
\end{tabular}

\section{Shrimp rearing and feces collection}

The shrimp was acclimated in fiber tank for 7 days. The tanks in digestibility test were 6 plastic tank sized in $77 \times 54 \times 45 \mathrm{~cm}$ filled with sea water (salinity $25-28 \mathrm{~g} / \mathrm{L}$ ) and equipped with aeration. The average weight of experimental shrimp was $5.73 \pm 0.38 \mathrm{~g}$ and the stocking density was 12 individuals $/$ tank $\left(29\right.$ individuals $\left./ \mathrm{m}^{2}\right)$. The shrimp was fed $8 \%$ of total biomass which adjusted to daily food requirement. The uneaten feed was collected. The feces was also collected three days after the experimental feed administration. The feces collection was conducted 2-3 hours after feeding. The feces was put into a film bottle and stored at $-20^{\circ} \mathrm{C}$ until the amount sufficient for analysis. 


\section{Experiment II: Growth test}

\section{Experimental feed preparation}

The experimental feed was crumble with three different level of $C$. racemosa meal addition ( 0 , 10,20 , and $30 \%$ ) according to the previous study by Putri et al. (2017). The experimental feed contained $42 \%$ of protein and $450 \mathrm{kcal} / 100 \mathrm{~g}$ of energy. The formulation and composition of the feed is presented in Table 2.

\section{Shrimp rearing and observation}

The shrimp was adapted for 7 days and fed using commercial feed. Before the study was begun, the shrimp was fasted for 24 hours. The rearing container was filled with seawater in salinity of $25-28 \mathrm{~g} / \mathrm{L}$ and equipped with aerations system. The container was covered using dark tarp to prevent the shrimp escape. As many of 100 individuals were collected to measure initial nutrition content. The average weight was $0.36 \pm$ $0.02 \mathrm{~g}$ and the stocking density was 15 individuals/ container (48 individuals $/ \mathrm{m}^{2}$ ). The shrimp was fed three times a day $(07.00,12.00$, and 17.00) and reared for 42 days. The amount of the feed was $8 \%$ of total biomass and it was adjusted to daily feed consumption. The body weight measurement was managed each two weeks. The uneaten feed and feces were collected using siphon, then water discharged was done approximately $30-50 \%$.

\section{Chemical analysis}

The chemical analysis consisted of chromium analysis (feed and feces), proximate analysis (the experimental feed, initial body weight, and final body weight), and also calcium and magnesium mineral analysis (C. racemosa meal, feed digestibility, and feces). All the procedure was refrred to AOAC (1990).

\section{Antioxidant activity test}

C. racemosa meal presented biological activity as antioxidant (Gaillande et al., 2016) and antibacterial because it contains phenol (Michalak \& Chojnacka, 2015). Superoxide

Table 2. The formulation of experimental feed for tiger shrimp with different level of C. racemosa meal.

\begin{tabular}{lcccc}
\hline \multirow{2}{*}{ Ingredients } & \multicolumn{4}{c}{ C. racemosa content } \\
\cline { 2 - 5 } & $0 \%$ & $10 \%$ & $20 \%$ & $30 \%$ \\
\hline Fish meal & 30.00 & 30.00 & 30.00 & 30.00 \\
Soybean meal & 28.00 & 23.00 & 18.00 & 14.00 \\
Squid meal & 5.00 & 5.00 & 5.00 & 5.00 \\
Polard & 20.00 & 17.00 & 14.00 & 8.00 \\
Wheat flour & 10.40 & 7.40 & 4.40 & 3.40 \\
C. racemosa meal & 0.00 & 10.00 & 20.00 & 30.00 \\
Coconut oil & 1.00 & 2.00 & 3.00 & 4.00 \\
Squid oil & 2.00 & 2.00 & 2.00 & 2.00 \\
Lecythin & 1.00 & 1.00 & 1.00 & 1.00 \\
Premix ${ }^{1}$ & 2.00 & 2.00 & 2.00 & 2.00 \\
Vitamin C & 0.10 & 0.10 & 0.10 & 0.10 \\
CMC & 0.50 & 0.50 & 0.50 & 0.50 \\
\hline Feed proximate $(\%)$ & & & & \\
\hline Protein & 42.18 & 43.25 & 42.65 & 42.69 \\
Lipid & 9.34 & 10.61 & 12.18 & 13.47 \\
Crude fiber & 2.54 & 2.54 & 2.29 & 2.17 \\
Ash & 9.38 & 10.66 & 12.37 & 13.59 \\
NFE & 36.57 & 32.94 & 30.51 & 28.08 \\
Energy (kcal/100g) & 473.93 & 476.99 & 478.41 & 480.78 \\
\hline
\end{tabular}

Premix (g/kg feed): Vit A $50 \mathrm{IU}$, vit $\mathrm{D}_{3} 10 \mathrm{IU}$, vit $\mathrm{B}_{1} 100 \mu \mathrm{g}$, vit $\mathrm{B}_{2} 200 \mu \mathrm{g}$, vit $\mathrm{B}_{6} 200 \mu \mathrm{g}$, vit $\mathrm{B}_{12} 0.25 \mu \mathrm{g}$, vit E $600 \mu \mathrm{g}$, vit $\mathrm{K}_{3} 50 \mu \mathrm{g}$, niacin $650 \mu \mathrm{g}$, panthotenic acid $300 \mu \mathrm{g}$, biotin $5 \mu \mathrm{g}$, follic acid $40 \mu \mathrm{g}$, inositol $1.000 \mu \mathrm{g}$, vit C $400 \mu \mathrm{g}$, phosphorus $280 \mu \mathrm{g}$, potassium $5.600 \mu \mathrm{g}$, calcium $5.600 \mu \mathrm{g}$, magnesium $1.820 \mu \mathrm{g}$, sodium $8.400 \mu \mathrm{g}$, iodin $196 \mu \mathrm{g}$, copper $1.4 \mu \mathrm{g}$, irone $332 \mu \mathrm{g}$, manganese $3.5 \mu \mathrm{g}$, and zinc $33.6 \mu \mathrm{g}$.

${ }^{2}$ Protein $5.6 \mathrm{kcal} \mathrm{GE}$, lipid $9.5 \mathrm{kcal} \mathrm{GE}$, carbohydrate $4.1 \mathrm{kcal} \mathrm{GE}$ (NRC, 2011). NFE = Nitrogen-free extract 
dismutase (SOD) enzyme is an indicator to measure antioxidant activity. SOD enzyme is the major antioxidant enzyme to prevent reactive oxygen species (ROS) and convert superoxide free-radical to peroxide $\left(\mathrm{H}_{2} \mathrm{O}_{2}\right)$ (Taylor \& Savin, 2011). The SOD enzyme test was begun with blood collection (hemolymph) at the end of the study, presicely 24 hours after feeding.

\section{Data collection}

The digestibility of $C$. racemosa was calculated through base feed and experimental feed digestibility. The method referred to Bureau \& Hua (2006). Growth performance was monitored through feed consumption, feed efficiency, protein efficiency ratio, feed conversion ratio (Takeuchi, 1988), specific growth rate (Halver, 1989), and survival rate.

\section{Statistical analysis}

All of the data were tabulated using Microsoft Excel 2013. Furthermore, the digestibility of C. racemosa meal was analyzed descriptively. On the contrary, growth parameter consisted of feed consumption, nutrition proximate of the shrimp, and SOD enzyme activity was analyzed statistically through parametric test (analysis of variance) using SPSS 16.0 and Duncan posthoc test in $95 \%$ of confidence level.

\section{RESULTS AND DISCUSSIONS}

\section{Results}

The digestibility of $C$. racemosa

The digestibility of $C$. racemosa meal was calculated from both base feed and experimental feed which measured through total digestibility, protein, calcium, magnesium, and energy. Those results are presented below in Table 3 .

Table 3. The digestibility of $C$. racemosa meal in tiger shrimp

\begin{tabular}{lc}
\hline Experimental parameter & Digestibility $(\%)$ \\
\hline Total digestibility & $51.82 \pm 2.15$ \\
Protein digestibility & $88.67 \pm 1.27$ \\
Calcium digestibility & $68.44 \pm 2.51$ \\
Magnesium digestibility & $16.39 \pm 3.99$ \\
Energy digestibility & $60.30 \pm 1.29$ \\
\hline
\end{tabular}

\section{Growth performance}

C. racemosa meal addition until $10 \%$ resulted similar amount of feed consumption with the control treatment. However, C. racemosa meal addition exceeded $20 \%$, decreased feed consumption. Identical case was also found in specific growth rate, protein efficiency ratio, protein retention, feed conversion, and feed efficiency which followed similar result with control. Whereas, $C$. racemosa meal addition until $30 \%$ did not significantly affect survival rate (Table 4).

\section{SOD enzyme activity}

SOD enzyme activity test towards hemolymph showed that there was a rising level of SOD enzyme along with the increase of $C$. racemosa addition. The $30 \%$ of $C$. racemosa meal additition delivered higher result and significantly different with other treatments $(\mathrm{P}<0.05)$ (Figure 1$)$.

\section{Discussion}

Total digestibility of C. racemosa is $51.82 \%$ (Table 3). The digestibility of $C$. racemosa

Table 4. Growth performance of tiger shrimp fed with different level of C. racemosa meal addition (control, $10 \%$, $20 \%, 30 \%)$.

\begin{tabular}{lcccc}
\hline \multirow{2}{*}{ Parameter } & \multicolumn{4}{c}{ C. racemosa addition } \\
\cline { 2 - 5 } & $0 \%$ & $10 \%$ & $20 \%$ & $30 \%$ \\
\hline $\mathrm{W}_{42}(\mathrm{~g})$ & $1.25 \pm 0.04^{\mathrm{a}}$ & $1.22 \pm 0.03^{\mathrm{a}}$ & $1.03 \pm 0.07^{\mathrm{b}}$ & $0.95 \pm 0.05^{\mathrm{b}}$ \\
Feed consumption (g/individual) & $1.90 \pm 0.06^{\mathrm{a}}$ & $1.87 \pm 0.10^{\mathrm{a}}$ & $1.77 \pm 0.07^{\mathrm{ab}}$ & $1.67 \pm 0.08^{\mathrm{b}}$ \\
SGR (\%/day) & $3.10 \pm 0.08^{\mathrm{a}}$ & $3.04 \pm 0.06^{\mathrm{a}}$ & $2.59 \pm 0.13^{\mathrm{b}}$ & $2.40 \pm 0.14^{\mathrm{b}}$ \\
PER & $1.11 \pm 0.02^{\mathrm{a}}$ & $1.06 \pm 0.03^{\mathrm{a}}$ & $0.88 \pm 0.04^{\mathrm{b}}$ & $0.82 \pm 0.04^{\mathrm{b}}$ \\
PR (\%) & $16.74 \pm 0.83^{\mathrm{a}}$ & $16.15 \pm 0.35^{\mathrm{a}}$ & $12.46 \pm 0.15^{\mathrm{b}}$ & $11.64 \pm 1.00^{\mathrm{b}}$ \\
FCR & $2.14 \pm 0.04^{\mathrm{a}}$ & $2.18 \pm 0.07^{\mathrm{a}}$ & $2.66 \pm 0.13^{\mathrm{b}}$ & $2.86 \pm 0.12^{\mathrm{b}}$ \\
FE (\%) & $46.80 \pm 0.94^{\mathrm{a}}$ & $45.90 \pm 1.47^{\mathrm{a}}$ & $37.63 \pm 1.75^{\mathrm{b}}$ & $35.02 \pm 1.55^{\mathrm{b}}$ \\
SR (\%) & $93.33 \pm 0.00^{\mathrm{a}}$ & $95.56 \pm 3.85^{\mathrm{a}}$ & $93.33 \pm 0.00^{\mathrm{a}}$ & $95.56 \pm 3.85^{\mathrm{a}}$ \\
\hline Note: The
\end{tabular}

Note: The stated value is average \pm deviation standard. Different superscript letter in the same row indicates significant difference $(\mathrm{P}<0.05) ; \mathrm{W}_{42}=$ individual final weight $($ day-42); $\mathrm{SGR}=$ specific growth rate; $\mathrm{PER}=$ protein efficiency ratio; $\mathrm{PR}=$ protein ratio; $\mathrm{FCR}=$ feed conversion ratio; $\mathrm{FE}=$ feed efficiency; $\mathrm{SR}=$ survival rate. 


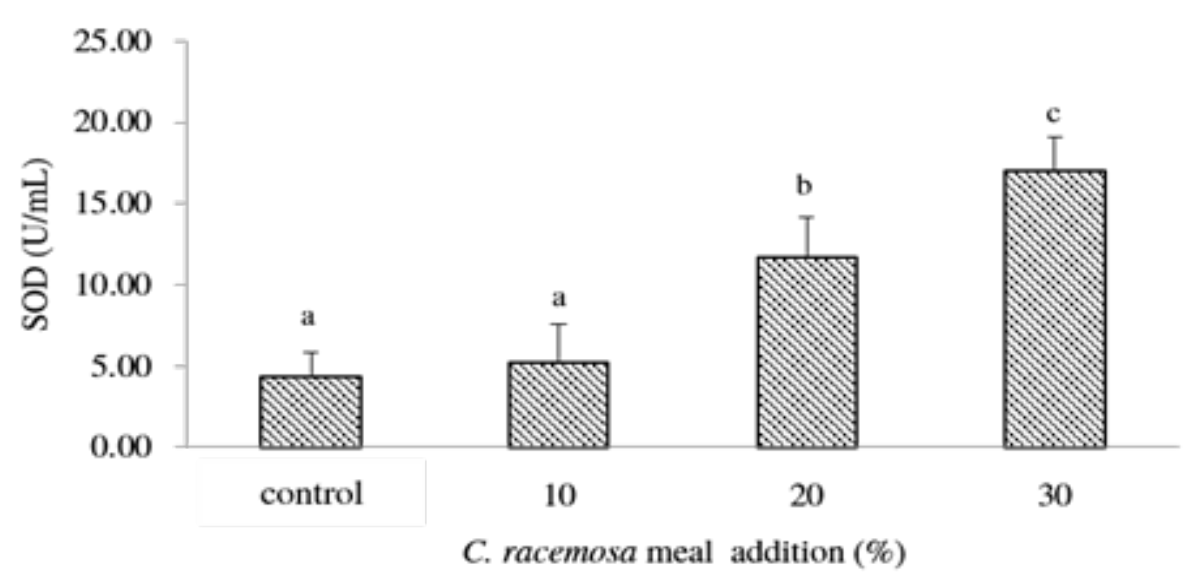

Figure 1. SOD enzyme activity in different level of C. racemosa meal addition (control, 10\%, 20\%, 30\%). Different letter in the graph indicates significant difference $(\mathrm{P}<0.05)$.

was considerably lower than soybean meal (60.1-73\%) and fish meal (74\%) (Smith et al., 2000). However, the digestibility of $C$. racemosa was noticeably higher than poultry by-product meal (PBM) (47.9\%) (Luo et al., 2012), meat meal $(43 \%)$, canola (49\%), and lupin (39\%) (Smith et al., 2000). Total digestibility represents total quantity of the digested material (Luo et al., 2012). A material can not be entirely digested, so that there is a variable named total digestibility to represent the digested and undigested material (Sookying et al., 2013)

A high protein content of C. racemosa (30\%) was highly digested by the tiger shrimp around $87.42 \%$ (Table 3). According to NRC (2011), the protein digestibility of shrimp ranges from 75-95\%. The digestibility of $C$. racemosa was noticeably higher than canola meal (80\%), cottonseed meal $(83 \%)$, and blood meal $(66 \%)$ (Smith et al., 2000; NRC, 2011). However, the digestibility of $C$. racemosa meal was lower than soybean meal $(92.1 \%)$ (Hertrampf \& Pascual, 2000; Smith et al., 2000). The protein content of $C$. racemosa was considerably higher than the other species of green algae, such as Enteromorpha intestinalis (24.52\%) and Ulva lactuca $(21.06 \%)$ (Ratana-arporn \& Chirapart, 2006). A decent level of digestibility is crucial in a high density aquaculture. The accumulation of uneaten feed potentially interrupts water quality, expands maintenance cost, and causes death (Lin et al., 2006; Hasan et al., 2012; Mohanty et al., 2014).

The digestibility of calcium and magnesium in the C. racemosa meal was $68.44 \%$ and $16.39 \%$, respectively (Table 3 ). The calcium requirement of the shrimp is $0.5-1.25 \%$, while the shrimp requires magnesium as many of $0.1-0.3 \%$ (Hertrampf \& Pascual, 2000; Hena et al., 2012).
Calcium held several roles in bone formation, muscle contraction, and blood vessel. On the other hand, magnesium is necessarily needed in cell respiration, enzyme activator, and also in lipid, carbohydrate, and protein metabolism (NRC, 2011; Antony et al., 2015; Bernard \& Bolatito, 2016). Shrimp has the ability to directly absorb several minerals, such as magnesium and calcium, in the water through the gill and exoskeleton in a low concentration yet (Hertrampf \& Pascual, 2000; NRC, 2011; Verma \& Tomar, 2014). Hence, mineral addition is inevitably essential to fulfill shrimp requirement (Roy et al., 2009; Pine \& Boyd, 2010).

The energy digestibility of $C$. racemosa was $60.30 \%$ (Table 3 ) which was lower than the energy digestibility of soybean meal $(71-76 \%)$ and poultry by-product meal (PBM) (82\%) (Smith $e t$ $a l, .2000 ;$ NRC, 2011). The value showed positive correlation with the protein digestibility of soybean meal which was higher than $C$. racemosa meal. However, the energy digestibility was nearly similar with the other plant-based ingredients, such as cottonseed meal (61\%) and cornmeal $(60 \%)$ (NRC, 2011) and higher than canola (53\%) and lupin meal (45\%) (Smith et al., 2000).

The diminishing level of growth performance along with the increasing level of $C$. racemosa dosage was assumed caused by the downturn of ingredients quality. The experimental feed was made isoprotein and isoenergy, thus the lower level of growth performance was supposedly caused by the low quality of the feed ingredients. According to Luis et al. (2010) and Sudaryono et al. (1999), a low quality of feed ingredients is possibly generated by low palatability which also leads to low feed consumption. Kamal and Sethuraman (2012) and Gaillande et al. (2016) mentioned that $C$. racemosa has a secondary metabolite 
compound in the methanol faction named caulerpin. This compound seemed unpalatable and it directly affected the feed attractiveness, especially in the higher dosage ( $>20 \%)$. Luis et $a l$. (2010) also reported that $C$. racemosa released antifeeding chemical compound which also presumably decreased the feed consumption of Thalassoma pavo.

Feed palatability is essential to attract the shrimp to consume the feed. Being slow and rely on its chemoreceptor are the habits of the shrimp to discover the feed (Smith et al., 2000; Aggio et al., 2012; Tantikitti, 2014). Caulerpin is known to own undesirable taste for the shrimp, so that the feed consumption decreased. In addition, feed palatability is precisely affected by attractant content. Glycine and alanine amino acids are known as decent attractant for shrimp (Sudaryono et al., 1999). Soybean meal contents glycine and alanine as many of $1.69 \%$ and $2.02 \%$, respectively (Song et al., 2008), compared with $C$. racemosa meal which contents glycine and alanine $1.28 \%$ dan $0.2 \%$, respectively (Bhuiyan et al., 2016). The addition of $C$. racemosa meal up to $20 \%$, led to lower percentage of soybean meal in the feed formulation (Table 2), thus the concentration of glycine and alanine decreased as well. As a consequence, feed palatability was also declined.

The declining level of growth performance was apparentely caused by caulerpin which activated after being consumed. It was shown by the increasing level of SOD enzyme (Figure 1). SOD enzyme is the major antioxidant enzyme that prevents reactive oxygen species (ROS) through counteracting free radical and phagocytosis (Matanjun et al., 2010; Zhang et al., 2013; Box et $a l ., 2008)$. The SOD enzyme increases along with the higher level of C. racemosa dosage. The 30\% of $C$. racemosa treatment resulted in $16.97 \mathrm{U} / \mathrm{mL}$ of SOD enzyme and it was different significantly with the other treatments. The increase level of SOD enzyme was assumed to anticipate ROS as a result of detoxification process towards caulerpin. Liu et al. (2009) stated that caulerpin inhibits hypoxia-inducible factor-1 (HIF-1) which controls oxygen homeostasis. When the HIF-1 is inhibited, ROS will be produced and it will lead to hypoxia condition. Metabolism rate will increase to produce SOD enzyme to prevent ROS. The increase of metabolism rate is not followed by an adequate energy supply. Felline et al. (2012) reported that caulerpin was also found in body tissues of white seabream Diplodus sargus fed using C. racemosa. As a consequence, a detoxification mechanism increased and it decelerated the growth performance.

The deficiency of feed causes the nutrient deficiency, thus the nutrient retention is declining. Protein retention (PR) presents the amount of protein retented from the digested feed. The feed is basically the energy source to fulfill the basal metabolism, daily maintenance, and growth necessity (Hu et al., 2008; Kaushik \& Seiliez, 2010). The protein retention of C. racemosa $10 \%$ treatment was $16.15 \%$ which not significantly different with control treatment (16.74\%) (Table 4). On the contrary, the protein retained in the $20 \%$ and $30 \%$ treatment decreased gradually and differ significantly with the $0 \%$ and $10 \%$ treatment. It also straightly affected the declining of protein efficiency ratio (PER). The PER result of $10 \%$ C. racemosa treatment was 1.06 and it was not significantly different with control $(\mathrm{P}>0.05)$. The C. racemosa addition until $10 \%$ was assumed as a proper composition as protein source for tiger shrimp feed. On the other hand, C. racemosa addition more than $20 \%$ generated lower value of PER. A lower value of PER indicated that protein was used to achieve energy demand. It also implied that energy demand from non-protein energy sources, such as lipid and carbohydrates, have not fulfilled yet.

The decreased growth performance was caused by feed digestibility presumably. Feed digestibility is required to discover feed quality and show the digested nutrient composition and absorbed by the shrimp to support its growth and metabolism (Luo et al., 2012). The addition of $C$. racemosa exceeded $20 \%$ caused the soybean meal substitution more than 35\% (Table 2). The total digestibility of soybean meal is $73 \%$ (Smith et al., 2000) and the protein digestibility ranges from 92.1-94.0\% (Hertrampf \& Pascual, 2000; NRC, 2011). Those values is higher than $C$. racemosa meal with total digestibility $51.82 \%$ and protein $87.42 \%$ (Table 3 ).

The specific growth rate (SGR) resulted by $10 \%$ of $C$. racemosa treatment was $3.04 \% /$ day which not significantly different with control (3.10\%/day). In contrast, C. racemosa addition exceeded $20 \%$ showed lower SGR. It could be generated by inefficient feed consumption, especially protein retention, which led to low growth rate. Feed conversion ratio (FCR) is an indicator to determine feed effectivity. A low feed conversion ratio indicates high feed efficiency. 
The FCR value of $10 \%$ C. racemosa treatment was 2.18 and it did not differ significantly with control treatment (2.14). It indicated that the feed efficiency of both treatments were similar (Table 4). Conversely, the $20 \%$ and $30 \%$ of C. racemosa treatment demonstrated higher FCR value and low feed efficiency value (Table 4). The results explained that $10 \%$ of $C$. racemosa addition was more efficient compared with $20 \%$ or above. Feed efficiency (FE) value is applied in weight added and feed consumption ratio (Watanabe, 1988; Richard et al., 2010). Consumed feed will produce a value which describes feed efficient utilized by the experimental shrimp. The FE value describes the most efficient treatment in terms of energy fulfillment and growth. The FE value in this study was higher compared to the result by Widyantoko et al. (2015) which used 3\% of Sargassum sp. meal in the experimental feed (33.19\%).

The survival rate of tiger shrimp presented unsignificant difference amongst treatments $(\mathrm{P}>0.05)$. It indicated that the addition of $C$. racemosa meal into the shrimp diet did not cause death on the experimental shrimp and it could be used as feed ingredient. A moderate toxic compound named caulerpin was able to be anticipated through SOD enzyme mechanism.

\section{CONCLUSION}

A $10 \%$ of Caulerpa racemosa is potentially used as tiger shrimp diet ingredient. A higher level of Caulerpa racemosa addition may diminish the growth rate of tiger shrimp Penaeus monodon.

\section{ACKNOWLEDGMENT}

Authors deliver sincere grateful the Marine and Fisheries Education Center, Ministery of Fisheries and Marine Affairs, Indonesia for fully funding this research with project no. 74/SJ/ KP.530/III/2016.

\section{REFERENCES}

[AOAC] Association of Official Analytical Chemists. 1990. Official methods of analysis. 15th edition. Association of Official Analytical Chemists. Washington D.C. 1094p.

Aggio JF, Tieu R, Wei A, Derby CD. 2012. Oesophageal chemoreceptors of blue crabs, Callinectes sapidus, sense chemical deterrents and can block ingestion of food. Journal of Experimental Biology 215: 1700-1710.
Antony J, Vungurala H, Saharan N, Reddy AK, Chadha NK, Lakra WS, Roy LA. 2015. Effects of salinity and $\mathrm{Na}^{+} / \mathrm{K}^{+}$ratio on osmoregulation and growth performance of black tiger prawn, Penaeus monodon Fabricius, 1798, juveniles reared in inland saline water. Journal of the World Aquaculture Society 46: 171-182.

Bernard E, Bolatito AY. 2016. Comparative study on the nutritional composition of the pink shrimp (Penaeus notialis) and tiger shrimp (Penaeus monodon) from Lagos lagoon, Southwest Nigeria. Cogent Food \& Agriculture 2: 1-7.

Bhuiyan KA, Qureshi S, Mustafa Kamal AH, Aftabuddin S, Siddique AM. 2016. Proximate chemical composition of sea grapes Caulerpa racemosa (J. Agardh. 1873) collected from a sub-tropical coast. Virology Mycology 5: 1-6.

Box A, Sureda A, Terrados J, Pons A, Deudero S. 2008. Antioxidant response and caulerpenyne production of the alien Caulerpa taxifolia (Vahl) epiphytized by the invasive algae Lophocladia lallemandii (Montagne). Journal of Experimental Marine Biology and Ecology 364: 24-28.

Bureau DP, Hua K. 2006. Letter to the editor of aquaculture. Aquaculture 252: 103-105.

Chen J, Li X, Xu H, Sun W, Leng X. 2017. Substitute of soy protein concentrate for fish meal in diets of white shrimp (Litopenaeus vannamei Boone). Aquaculture International 25: 1303-1315.

Cruz-Suarez LE, Tapia-Salazar M, VillarealCavazos D, Beltran-Rocha J, Nieto-Lopez MG, Lemme A, Ricque-Marie D. 2009. Apparent dry matter, energy, protein, and amino acid digestibility of four soybean ingredients in white shrimp Litopenaeus vannamei juveniles. Aquaculture 292: 87-94.

Derby CD, Elsayed FH, Williams SA, González C, Choe M, Bharadwaj AS, Chamberlain GW. 2016. Krill meal enhances performance of feed pellets through concentrationdependent prolongation of consumption by Pacific white shrimp, Litopenaeus vannamei. Aquaculture 458: 13-20.

Difo VH, Onyike E, Ameh DA, Njoku GC, Ndidi US. 2015. Changes in nutrient and antinutrient composition of Vigna racemosa flour in open and controlled fermentation. Journal of Food Science and Technology 52: 6043-6048.

Dolomatov SI, Kubyshkin AV, Zukow WA, Kutya SA, Cieslicka M, Muszkieta R, Napierala M. 2014. Prospects for the replenishment of a 
feed protein deficit in aquaculture. Russian Journal of Marine Biology 40: 233-240.

Draganovic V, Boom RM, Jonkers J, van der Goot AJ. 2014. Lupine and rapeseed protein concentrate in fish feed: A comparative assessment of the techno-functional properties using a shear cell device and an extruder. Journal of Food Engineering 126:178-189.

Felline S, Caricato R, Cutignano A, Gorbi S, Lionetto MG, Mollo E, Regolli F, Terlizzi A. 2012. Subtle effects of biological invasions: cellular and physiological responses of fish eating the exotic pest Caulerpa racemosa. Plos One 7: 1-10.

Gaillande C, Payri C, Remissenet G, Zubia M. 2016. Caulerpa consumption, nutritional value, and farming in the Indo-Pacific region. Journal of Applied Phycology 29: 1-18.

Halver JE. 1989. Fish Nutrition. New York: Academic Pr.

Hasan BMA, Guha B, Datta S. 2012. Optimization of feeding efficiency for cost effective production of Penaeus monodon Fabricius in semi-intensive pond culture system. Journal of Aquaculture Research \& Development 3: $1-7$.

Hena MA, Idris MH, Wong SK. 2012. Chemical composition of water from tiger shrimp Penaeus monodon culture ponds at Malacca, Malaysia. International Journal of Agriculture and Biology 14: 395-400.

Hertrampf JW, Piedad-Pascual F. 2000. Fish Protein Concentrate (Hydrolysed). In Handbook on Ingredients for Aquaculture Feeds. Springer. Dordrecht. pp. 192-197.

Hu Y, Tan B, Mai K, Ai Q, Zheng S, Cheng K. 2008. Growth and body composition of juvenile white shrimp. Litopenaeus vannamei. fed different ratios of dietary protein to energy. Aquaculture Nutrition 14: 499-506.

Kalaivanan C, Chandrasekaran M, Venkatesalu V. 2012. Effect of seaweed liquid extract of Caulerpa scalpelliformis on growth and biochemical constituents of black gram (Vigna mungo (L.) Hepper). Phykos 42: 46-53.

Kamal C, Sethuraman MG. 2012. Caulerpin-A bis-indole alkaloid as a green inhibitor for the corrosion of mild steel in $1 \mathrm{M} \mathrm{HCl}$ solution from the marine alga Caulerpa racemosa. Industrial \& Engineering Chemistry Research 51: 10399-10407.

Kaushik SJ, Seiliez I. 2010. Protein and amino acid nutrition and metabolism in fish: current knowledge and future needs. Aquaculture Research 41: 322-332.

Kou H, Xu S, Wang AL. 2015. Effect of replacing canola meal for fish meal on the growth, digestive enzyme activity, and amino acids, of ovate pompano, Trachinotus ovatus. The Israeli Journal of Aquaculture-Bamidgeh 67: $1-10$.

Kumar M, Kumari P, Trivedi N, Shukla MK, Gupta V, Reddy CRK, Jha B. 2011. Minerals, PUFAs and antioxidant properties of some tropical seaweeds from Saurashtra coast of India. Journal of Applied Phycology 23: $797-$ 810.

Lin HZ, Li ZJ, Chen YQ, Zheng WH, Yang K. 2006. Effect of dietary traditional Chinese medicines on apparent digestibility coefficients of nutrients for white shrimp Litopenaeus vannamei. Boone. Aquaculture 253: 495-501.

Liu Y, Morgan JB, Coothankandaswamy V, Liu R, Jekabsons MB, Mahdi F, Nagle DG, Zhou YD. 2009. The caulerpa pigment caulerpin inhibits HIF-1 activation and mitochondrial respiration. Journal of Natural Products 72: 2104-2109.

Luis MV, Jerez PS, Sempere JTB. 2010. Effects of Caulerpa racemosa var. cylindracea on prey availability: an experimental approach to predation of amphipods by Thalassoma pavo (Labridae). Hydrobiologia 654: 147-154.

Luo L, Wang J, Pan Q, Xue M, Wang Y, Wu X, Li P. 2012. Apparent digestibility coefficient of poultry by-product meal (PBM) in diets of Penaeus monodon (Fabricius) and Litopenaeus vannamei (Boone). and replacement of fishmeal with PBM in diets of P. monodon. Aquaculture Research 43: 1223-1231.

MacArtain P, Gill CI, Brooks M, Campbell R, Rowland IR. 2007. Nutritional value of edible seaweeds. Nutrition Reviews 65: 535-543.

Matanjun P, Mohamed S, Mustapha NM, Muhammad K. 2009. Nutrient content of tropical edible seaweeds. Eucheuma cottonii, Caulerpa lentillifera, and Sargassum polycystum. Journal of Applied Phycology 21: 75-80.

Matanjun P, Mohamed S, Muhammad K, Mustapha NM. 2010. Comparison of cardiovascular protective effects of tropical seaweeds, Kappaphycus alvarezii, Caulerpa lentillifera, and Sargassum polycystum, on high-cholesterol/high-fat diet in rats. Journal of Medicinal food 13: 792-800. 
Michalak I, Chojnacka K. 2015. Algae as production systems of bioactive compounds. Engineering in Life Sciences 15: $160-176$.

Mohanty RK, Mishra A, Patil DU. 2014. Water budgeting in black tiger shrimp Penaeus monodon culture using different water and feed management systems. Turkish Journal of Fisheries and Aquatic Sciences 14: 487-496.

Murugaiyan K, Narasimman S. 2013. Biochemical and mineral contents of selected green seaweeds from Gulf of Mannar coastal region, Tamil Nadu, India. International Journal of Research in Plant Science 3: 96-100.

Nagappan T, Vairappan CS. 2014. Nutritional and bioactive properties of three edible species of green algae, genus Caulerpa (Caulerpaceae). Journal of Applied Phycology 26: 1019-1027.

[NRC] National Research Council. 2011. Nutrient requirements of fishes. Washington DC (US): National Academy of Sciences.

Oujifard A, Seyfabadi J, Kenari AA, Rezaei M. 2012. Fish meal replacement with rice protein concentrate in a practical diet for the Pacific white shrimp, Litopenaeus vannamei Boone. 1931. Aquaculture International 20: 117-129.

Paul NA, Neveux N, Magnusson M, de Nys R. 2013. Comparative production and nutritional value of "sea grapes" the tropical green seaweeds Caulerpa lentillifera and $C$. racemosa. Journal of Applied Phycology 26: 1833-1844.

Pine HJ, Boyd CE. 2010. Adsorption of magnesium by bottom soils in inland brackish water shrimp ponds in Alabama. Journal of the World Aquaculture Society 41: 603-609.

Putri NT, Jusadi D, Setiawati M, Sunarno MTD. 2017. Potential use of green algae Caulerpa lentillifera as feed ingredient in the diet of Nile tilapia Oreochromis niloticus. Jurnal Akuakultur Indonesia 16: 184-192.

Ratana-arporn P, Chirapart A. 2006. Nutritional evaluation of tropical green seaweeds Caulerpa lentillifera and Ulva reticulate. Kasetsart Journal 40: 75-83.

Richard L, Blanc PP, Rigolet V, Kaushik SJ, Geurden I. 2010. Maintenance and growth requirements for nitrogen, lysine and methionine and their utilisation efficiencies in juvenile black tiger shrimp, Penaeus monodon, using a factorial approach. British journal of nutrition 103: 984-995.

Roy LA, Davis DA, Nguyen TN, Saoud IP. 2009. Supplementation of chelated magnesium to diets of the pacific white shrimp, Litopenaeus vannamei, reared in low-salinity waters of west Alabama. Journal of The World Aquaculture Society 40: 248-254.

Samuelsen TA, Mjos SA, Oterhals A. 2014. Influence of type of raw material on fishmeal physicochemical properties, the extrusion process, starch gelatinization and physical quality of fish feed. Aquaculture Nutrition 20: 410-420.

Santoso J, Gunji S, Yoshi-Strak Y, Suzuki T. 2006. Mineral contents of Indonesian seaweeds and mineral solubility afected by basic cooking. Food Science and Technology Research 12: 59-66.

Schader C, Muller A, Scialabba NEH, Hecht J, Isensee A, Erb KH, Schwegler P. 2015. Impacts of feeding less food-competing feedstuffs to livestock on global food system sustainability. Journal of the Royal Society Interface 12: 1-12.

Sharawy Z, Goda AMS, Hassaan MS. 2016. Partial or total replacement of fish meal by solid state fermented soybean meal with Saccharomyces cerevisiae in diets for Indian prawn shrimp, Fenneropenaeus indicus, postlarvae. Animal Feed Science and Technology 212: 90-99.

Singh, R, Chatli MK, Biswas AK, Sahoo J. 2014. Quality of $\omega-3$ fatty acid enriched low-fat chicken meat patties incorporated with selected levels of linseed flour/oil and canola flour/oil. Journal of Food Science and Technology 51: 353-358.

Smith DM, Allan GL, Williams KC, Barlow C. 2000. Fishmeal replacement research for shrimp feed in Australia. In: Cruz-Suarez LE, Ricque-Marie D, Tapia-Salazar M, OlveraNovoa MA, Civera-Cerecedo R. editor. Avances en Nutricion Acuicola V. Memorias del V Simposium Internacional de Nutricion Acuicola. 19-22 November. 2000. Merida. Yucatan. Mexico.

Song YS, Frias J, Villaluenga CM, Valdeverde CV, Mejia EG. 2008. Immunoreactivity reduction of soybean meal by fermentation, effect on amino acid composition and antigenicity of commercial soy products. Food Chemistry 108: 571-581.

Sookying D, Davis DA, Soller Dias Da Silva F. 2013. A review of the development and application of soybean-based diets for Pacific white shrimp Litopenaeus vannamei. Aquaculture Nutrition 19: 441448. 
Suárez JA, Gaxiola G, Mendoza R, Cadavid S, Garcia G, Alanis G, Suárez A, Faillace J, Cuzon G. 2009. Substitution of fish meal with plant protein sources and energy budget for white shrimp Litopenaeus vannamei (Boone, 1931). Aquaculture 289: 118-123.

Sudaryono A, Tsvetnenko E, Evans LH. 1999. Evaluation of potential of lupin meal as an alternative to fish meal in juvenile Penaeus monodon diets. Aquaculture nutrition 5: 277 285.

Takeuchi T. 1988. Laboratory work chemical evaluation of dietary nutrition. In: [Fish nutrition and mariculture]. JICA textbook the general aquaculture course. Watanabe T. (Ed). Tokyo. Kanagawa International Fish Training Center. 224p.

Tantikitti C. 2014. Feed palatability and the alternative protein sources in shrimp feed. Songklanakarin Journal of Science and Technology 36: 51-55.

Taylor DPP, Savin TZ. 2011. Antioxidant enzyme activities in Pacific white shrimp Litopenaeus vannamei in response to environmental hypoxia and reoxygenation. Aquaculture 318: 379-383.

Verma D, Tomar V. 2014. An investigation into environment dependent nanomechanical properties of shallow water shrimp (Pandalus platyceros) exoskeleton. Materials Science and Engineering C 44: 371-379.

Watanabe. 1988. Fish Nutrition Ana Mariculture. Japan: Kanagawa International Fisheries Training Centre Japan International Cooperation Agency (JICA).

Widyantoko W, Pinandoyo, Herawati VE. 2015. Optimization addition of flour brown seaweed (Sargassum sp.) which different in feed on growth and survival rate of juvenile tiger shrimp Penaeus monodon. Journal of Aquaculture Management and Technology 4: 9-17.

Xie SW, Liu YJ, Zeng S, Niu J, Tian LX. 2016. Partial replacement of fish-meal by soy protein concentrate and soybean meal based protein blend for juvenile Pacific white shrimp, Litopenaeus vannamei. Aquaculture 464: 296-302.

Zhang J, Liu YJ, Tian LX, Yang HJ, Liang GY, Yue YR, Xu DH. 2013. Effects of dietary astaxanthin on growth, antioxidant capacity and gene expression in Pacific white Shrimp Litopenaeus vannamei. Aquaculture Nutrition 19: 917-927.

Zhou YG, Davis DA, Buentello A. 2015. Use of new soybean varieties in practical diets for the Pacific white shrimp, Litopenaeus vannamei. Aquaculture Nutrition 21: 635643. 